\section{Comparison of Commercial Boron Spray Products Applied at the Pink Flowering Stage on 'Fuji' Apple}

\author{
Frank J. Peryea ${ }^{1}$ \\ Tree Fruit Research and Extension Center, Washington State University, 1100 \\ North Western Avenue, Wenatchee, WA 98801
}

Additional index words. Malus $\times$ domestica, tree fruit, mineral nutrition, foliar spray, micronutrient

\begin{abstract}
Two multiyear field studies were conducted to compare the phytoavailability and effectiveness of a variety of commercial foliar B fertilizer sprays applied at the pink flowering stage to ' $\mathrm{Fuji}$ '/EMLA.26 apple trees grown under irrigated semi-arid conditions. Treatments included products that differed by initial chemical form of $B$, physical state, and presence of additives of varying composition. Additional treatments were polymeric urea added to one $B$ product and soil application of one $B$ product. Boron application rates varied from 0.56 to $1.68 \mathrm{~kg} \cdot \mathrm{ha}^{-1} \cdot \mathrm{yr}^{-1}$. All of the $B$ sprays increased flower cluster $B$ concentration in all years. The $B$ sprays at the lower rate sometimes but not always increased leaf $B$ concentration. Increasing the B rate substantially increased plant tissue $B$ concentrations. In general, there was little substantive difference between the tested products/product mixtures on plant tissue B concentrations. Flower cluster B in the ground-applied B treatment was similar to the water control; however, leaf B concentration corresponded to the B spray treatments, indicating effective uptake of $B$ from the soil during the early summer. Sodium polyborate-based products increased flower cluster $\mathrm{Na}$ concentration but not leaf $\mathrm{Na}$ concentration. The amount of $\mathrm{Na}$ contributed by $\mathrm{Na}$ polyborate-based products applied at commercial rates apparently was too small to be of horticultural concern. Fruit quality was excellent and was not affected by the experimental treatments in any year. Flower cluster and leaf $B$ concentrations returned to near or at control levels in the season following the last spray application, validating the recommendation for annual B fertilizer applications to maintain adequate tree B status.
\end{abstract}

Boron (B) insufficiency has been reported in apple orchards throughout the world (Overholser et al., 1937; Shorrocks and Nicholson, 1980). Application of prebloom B sprays is often used to ensure that sufficient amounts of B are available for pollen tube growth, flower fertilization, fruit set, and early fruitlet development (Peryea, 1992). Washington State University (WSU) guidelines encourage apple growers to apply annual maintenance sprays of B to ensure that fruit trees contain sufficient $\mathrm{B}$ for optimal tree growth and fruiting performance (Smith, 2004).

Soil applications of boric acid or borax, or foliar sprays of borax, were initially recommended to treat B deficiency (Overholser et al., 1937). Boric acid sprays were used experimentally (Batjer and Rogers, 1953; McLarty et al., 1936; Phillips and Johnston, 1943) but do not appear to have been adopted as commercial practice. Borax sprays were supplanted about 1953 by the Na polyboratebased Polybor (Pacific Coast Borax Co., Los Angeles, Calif.) (Burrell, 1960; Johnson et al.,

Received for publication 10 Aug. 2004. Accepted for publication 15 Jan. 2005. This research was conducted under Project WNP0747, College of Agricultural, Human, and Natural Resource Sciences, Washington State Univ., Pullman. Funding support was provided by the College and by the Washington Tree Fruit Research Commission. I thank Eugene Fairchild, Habib Khemira, Jennifer Moore, and Casimir Lorentz for their technical support.

${ }^{1}$ Research soil scientist.
1955; WSC, 1953), mainly because the latter product dissolved more quickly in the spray tank. Polybor soon was renamed Solubor(U.S. Borax, Valencia, Calif.), to prevent misapplication problems resulting from grower failure to properly distinguish between Polybor and the herbicide polybor chlorate (WSC, 1958). Solubor has been the most commonly recommended B spray product for a half-century, principally because of its efficacy and low cost (Peryea, 1992; Peryea et al., 2003).

During the past decade, numerous alternative B spray products have been introduced. Presumptive improvements include changes in solid state characteristics that improve dissolution rates and handling, less alkaline reaction which lowers risk of alkaline hydrolysis of $\mathrm{pH}$-sensitive compounds in tank-mix sprays, and additives to improve $\mathrm{B}$ uptake by plant tissue (Peryea and Lageschulte, 2000). The purpose of the current study was to evaluate the phytoavailability of B from commercially available B spray products and product mixtures applied at the pink flowering stage, and consequent effects on fruit quality.

\section{Materials and Methods}

Experimental boron product properties. The tested B spray products differed in initial chemical form of B, physical state, and presence of additives of varying composition (Table 1). Field experience indicates that the solid compounds B-17, Solubor DF, and Mor-Bor 17 are much less likely to cake and exhibit improved particle flow behavior in the dry state than do Solubor and SprayBor, and that the liquid products are convenient to measure and mix in spray water. All of the products cost more per unit B than does Solubor. The products raise or lower spray water $\mathrm{pH}$, depending on product composition and rates, and initial water chemistry (Peryea and Lageschulte, 2000).

Experimental sites. Two experiments were conducted in a 'Red Fuji'/EMLA.26 apple orchard planted in Spring 1993 on the east bank of the Columbia River south of Orondo, Wash. The natural environment is semi-arid sagebrush-steppe. Annual precipitation averages $265 \mathrm{~mm}$. Average January and July temperatures are -1.7 and $22^{\circ} \mathrm{C}$, respectively. The soil is classified as a Cashmont gravelly sandy loam (coarse-loamy, mixed, mesic Aridic Haploxeroll). The trees were planted at a $1.9 \mathrm{~m}$ $\times 4.6 \mathrm{~m}$ spacing (planting density 1148 trees per ha) and were supported by a metal conduit-wire trellis system. About every tenth tree within each row was a 'Royal Gala'/EMLA.26 apple serving as a pollinizer. The trees were irrigated using a permanent undertree high-pressure, high-volume sprinkler system. Herbicides were used to maintain a weed-free strip within the tree rows. Fruits were chemically and/or hand-thinned. Insect pests and diseases were managed according to commercial guidelines (Smith, 2004). With the exception of annual prebloom soil $\mathrm{N}$ applications $\left(78 \mathrm{~kg} \cdot \mathrm{ha}^{-1} \mathrm{~N}\right.$ as $\mathrm{NH}_{4} \mathrm{NO}_{3}$ ) and a postbloom $\mathrm{Zn}$ spray in 2000 (0.74 $\mathrm{kg} \cdot \mathrm{ha}^{-1} \mathrm{Zn}$ as basic Zn sulfate), no nutrients other than those in the experimental products were applied.

Experiment 1. In 1996, 10 experimental treatments were arranged in a randomized complete-block design replicated 5-fold. Each plot contained three trees, which comprised the sampling unit, from which flower cluster, leaf and fruit samples were collected and assessed for treatment responses.

Experimental treatments were one spray application per year of seven B-containing spray products, plus Solubor tank-mixed with added $\mathrm{N}$, and soil application of Solubor: 1)water control; 2) reagent-grade boric acid (1996 only) replaced in 1997-99 by the boric acid-based Mor-Bor 17, which became available in 1997; 3) Solubor; 4) Solubor DF; 5) Spraybor; 6) Borosol; 7) Liquibor; 8) N-Boron; 9) Solubor plus Coron (polymeric urea compound to enhance B uptake, CoRoN, Souderton, Pa.); and 10) Solubor applied only to the ground.

All treatments were applied each year at the full-pink flowering stage (19Apr. 1996;23 Apr. 1997; 17 Apr. 1998; and 22 Apr. 1999) using a truck-mounted high-pressure sprayer and single-nozzle Windmaster orchard handgun (Northwest Wholesale, Wenatchee, Wash.). Treatment solutions were sprayed to drip with the exception of Treatment 10 (ground-applied Solubor), which was sprayed over the surface of the herbicide strip area beneath the treatment trees (about $3.6 \mathrm{~m}^{2}$ per tree) for a period of time equivalent to the average time required to apply Treatment 3 (foliar Solubor). In 1996-98, all products were applied at a $B$ rate of $0.56 \mathrm{~kg} \cdot \mathrm{ha}^{-1}$ 
Table 1. Boron spray products evaluated in experiments.

\begin{tabular}{|c|c|c|c|c|c|}
\hline $\begin{array}{l}\text { Product } \\
\text { (experiment) }\end{array}$ & $\begin{array}{c}\text { Physical } \\
\text { state }^{z}\end{array}$ & $\begin{array}{c}\text { B } \\
\text { concn }^{y}\end{array}$ & $\begin{array}{l}\text { Form } \\
\text { of } B^{x}\end{array}$ & Additive & Manufacturer \\
\hline Orthoboric acid (1) & $\mathrm{S}$ & 17.5 & BA & None & Mallinckrodt, Paris, Ky. \\
\hline Albion Liquid Boron (2) & $\mathrm{L}$ & 5.0 & $\mathrm{NaB}$ & Amino acids & Albion Lab., Clearfield, Utah \\
\hline B-17 (2) & $\mathrm{S}$ & 17.0 & BA & Surfactant & Nutrient Technol., La Habra, Calif. \\
\hline Borosol-10 (1) & $\mathrm{L}$ & 10.0 & BA & Ethanolamine & Clean Crop, Fremont, Nebr. \\
\hline Boron X-tra (2) & $\mathrm{L}$ & 5.0 & BA & Acids, plant extracts, peptides & Custom Agric. Formulators, Fresno, Calif. \\
\hline Greenleaf Boron (2) & $\mathrm{L}$ & 1.75 & Unspecified & Carbohydrates & SafeScience, Boston, Mass. \\
\hline Mor-Bor $17(1,2)$ & $\mathrm{S}$ & 17.3 & $\mathrm{BA}$ & Surfactant & G.S. Long, Yakima, Wash. \\
\hline N-Boron (1) & $\mathrm{L}$ & 5.4 & $\mathrm{BA}$ & Urea, polysaccharides & Plant Health Technol., Boise, Idaho \\
\hline Solubor $(1,2)$ & $\mathrm{S}$ & 20.5 & $\mathrm{NaB}$ & None & U.S. Borax, Los Angeles, Calif. \\
\hline Solubor DF (1) & $\mathrm{S}$ & 17.4 & $\mathrm{NaB}$ & None & U.S. Borax, Los Angeles, Calif. \\
\hline SprayBor (1) & $\mathrm{S}$ & 16.5 & $\mathrm{NaB}$ & Acidifier & NutriAg, Toronto, Canada \\
\hline Tech-Spray Liquibor (1) & $\mathrm{L}$ & 2.5 & $\mathrm{BA}, \mathrm{NaB}$ & Surfactant & Nutrient Technol., Dinuba, Calif. \\
\hline
\end{tabular}

${ }^{\mathrm{z}} \mathrm{S}=$ solid; $\mathrm{L}=$ liquid.

yPercent $\mathrm{B}$ by weight.

${ }^{\times} \mathrm{BA}=$ boric acid; $\mathrm{NaB}=$ sodium polyborates of varying composition .

(current WSU maintenance rate). In 1999, all products were applied at a $\mathrm{B}$ rate equivalent to $1.12 \mathrm{~kg} \cdot \mathrm{ha}^{-1}$ (current WSU deficiency rate) because the leaf $B$ concentrations of the trees treated with B in the previous years had dropped below desirable levels. No treatments were applied to the treatment plots in 2000 to evaluate residual effects. The experimental $B$ rates exceeded the label rates for some of the products. Treatments 8 (N-Boron) and 9 (Solubor + Coron) each supplied the equivalent of $0.47 \mathrm{~kg} \mathrm{~N} / \mathrm{ha}$ in $1996-98$ and $0.94 \mathrm{~kg} \mathrm{~N} / \mathrm{ha}$ in 1999. Treatment 6 (Borosol) contains an unknown but very low amount of $\mathrm{N}$.

Experiment 2. In 1998, six experimental treatments were arranged in a randomized complete-block design, replicated fivefold, in the western half of the orchard used in Expt. 1. The plot design, spray application, and sampling procedures were identical to those used in Expt. 1.

Experimental treatments were one spray application per year of four or five (depending on year) B-containing spray products (Table 1): 1) water control; 2) Mor-Bor 17; 3) B-17; 4) Solubor; 5) Albion liquid B; 6a) in 1998 only, Greenleaf Boron Micro; and 6b) in 2000 only, Boron X-tra. Several of these products became available for testing after the start of Expt. 1; Mor-Bor 17 and Solubor were included as industry standards.

All treatments were applied at the full pink flower cluster stage (17 Apr. 1998; 22 Apr. 1999; and 13 Apr. 2000) each year. In 1998-99, all products were applied at a B rate of $0.56 \mathrm{~kg} \cdot \mathrm{ha}^{-1}$ (current WSU maintenance rate). In 2000, all products were applied at a $\mathrm{B}$ rate equivalent to $1.68 \mathrm{~kg} \cdot \mathrm{ha}^{-1}$ (1.5 times the current WSU deficiency rate) because the leaf B concentrations of the trees treated with $\mathrm{B}$ in the previous years had dropped below desirable levels and the results of Expt. 1 suggested that a higher rate was warranted. The experimental $\mathrm{B}$ rates exceeded the label rates for some of the products. The Greenleaf Boron Micro treatment was deleted from the study after 1998 because it was not going to be commercially produced. In 2000, Boron Xtra was added to the study because of grower interest, and was applied to the 1998 Greenleaf Boron Micro plots.

Plant tissue analyses. Each year, six flower clusters at the full bloom stage (late April/early May) were sampled randomly from each experimental plot and composited by plot. Eighteen leaves were sampled randomly using standard criteria (fully expanded leaves from middle third of terminal shoots growing at an angle of 30 to $60^{\circ}$ from horizontal) from each experimental plot in early August and composited by plot. The flower cluster samples were freeze-dried without washing because of their fragility. Use of this procedure means that measured mineral element concentrations in flower clusters from trees receiving treatment sprays at the pink flowering stage may be biased by the presence of spray residues on the plant tissue surfaces. Given the high rate of absorption of $\mathrm{B}$ and $\mathrm{Na}$ by growing leaf tissue (Maas, 1986; Shu et al., 1994), internal B and Na concentrations are expected to be positively related to total concentrations in the unwashed flower clusters. The leaf samples were washed in $0.5 \%$ Liquinox solution (Alconox, New York), followed by tap water and deionized water rinses, and oven-dried at $85{ }^{\circ} \mathrm{C}$. All dried plant tissue samples were ground and analyzed for N, P, K, Ca, Mg, S, Zn, B, Mn, $\mathrm{Fe}, \mathrm{Cu}, \mathrm{Al}$, and $\mathrm{Na}$ concentrations. Plant $\mathrm{N}$ was determined by total Kjeldahl digest and flow injection colorimetry, and the other mineral elements by wet-digestion, followed by assay using inductively coupled plasma optical emission spectroscopy. Plant tissue analytical data are reported on a dry mass basis.

Fruit quality assessment. Nine apples at commercial harvest stage were sampled randomly from each experimental plot at commercial harvest timing in mid-October 1998-2000. The fruit samples were composited by plot, placed into plastic fruit bags inside cardboard fruit boxes, and stored under refrigerated air $\left(1{ }^{\circ} \mathrm{C}\right)$ conditions. They were removed from storage after about $10 \mathrm{~d}$ and evaluated for the following fruit quality attributes: fresh mass, Hunter external color indices $L$ (lightness), $a_{\mathrm{e}}$ (red/green) and $b_{\mathrm{e}}$ (yellow/blue) using a color machine (Pacific Scientific, Silver Spring, Md.), firmness using an Electronic Pressure Tester (Lake City Technical Products, Kelowna, B.C.), soluble solids concentrations by Abbe-type refractometer, and titratable acidity by titration with $0.1 \mathrm{M} \mathrm{NaOH}$ to $\mathrm{pH}$ 8.2. Hue angle, an index of human percep- tion of fruit skin color, was calculated as 57.3 $\tan ^{-1}\left(b_{\mathrm{e}} / a_{\mathrm{e}}\right)$.

Statistical analyses. Although multiple sequential measurements were made on the same set of experimental trees, the comparisons of primary interest in the current study were the treatment responses within each individual year. The response data for each experiment therefore were analyzed for each year using separate analyses of variance (ANOVA) for a randomized complete block experimental design (Steel and Torrie, 1980). This approach offers the most powerful statistical test to evaluate the fixed effect of B treatment but does not allow quantitative inferences to be drawn about trends over time. Duncan's multiple range test was used for mean separation of significant treatment effects. Statistical analyses were carried out using the Proc GLM procedure of the computer program SAS for Windows, Version 6.12. Statistical significance was defined at $P \leq 0.05$.

\section{Results}

Visual observations. None of the trees at any time showed visual symptoms associated with B deficiency or toxicity (Oberly and Boynton, 1966). Blossom blast, witch's broom, leaf malformation, and other vegetative symptoms were absent. The harvested fruit did not exhibit cracking or internal breakdown (symptoms of B insufficiency) nor advanced ripening or firmness loss (symptoms of B excess). Malnutrition symptoms associated with other mineral elements also were absent.

Mineral element concentrations in plant tissues, Expt. 1. The foliarly applied B treatments had a very highly significant effect on flower cluster B in all years that the sprays were applied, increasing flower cluster B relative to the water control (Table 2). There were no differences between the foliar B sprays in 1996-97. Several differences between products appeared in 1998 and 1999. The boric acid-based Mor-Bor 17 produced the lowest flower cluster B concentration of all the B spray treatments in 1998 and remained at the low end of the range in the following year. Flower cluster B concentration in the SprayBor treatment was lower than those of several other B spray treatments in 1998-99. The remain- 
ing six product-product combinations were consistently among the grouping producing the greatest increase in flower cluster B in
1998-99. In 2000, when none of the experimental plots received $\mathrm{B}$, flower cluster $\mathrm{B}$ in most of the B-containing treatments remained
Table 2. Effect of B spray treatments applied at the full pink flowering stage on plant tissue B concentrations of 'Fuji' apple trees, Expt. 1.

\begin{tabular}{|c|c|c|c|c|c|}
\hline \multirow{2}{*}{$\begin{array}{l}\text { Spray } \\
\text { treatment }\end{array}$} & \multicolumn{5}{|c|}{ Year $^{2}$} \\
\hline & 1996 & 1997 & 1998 & 1999 & 2000 \\
\hline \multicolumn{6}{|c|}{ Boron concentration in flower clusters at full bloom $\left(\mathrm{mg} \cdot \mathrm{kg}^{-1}\right)$} \\
\hline Water control & $40.7 \mathrm{a}^{\mathrm{y}}$ & $30.0 \mathrm{a}$ & $24.2 \mathrm{a}$ & $23.0 \mathrm{a}$ & $26.4 \mathrm{a}$ \\
\hline Solubor, soil & $57.4 \mathrm{ab}$ & $38.4 \mathrm{a}$ & $34.9 \mathrm{a}$ & $30.7 \mathrm{a}$ & $49.4 \mathrm{~b}$ \\
\hline Borosol & $93.6 \mathrm{c}$ & $77.3 \mathrm{~b}$ & $96.9 \mathrm{~cd}$ & $215.2 \mathrm{~d}$ & $42.7 \mathrm{~b}$ \\
\hline Liquibor & $95.9 \mathrm{c}$ & $114.3 \mathrm{~b}$ & $99.9 \mathrm{~cd}$ & $180.0 \mathrm{~cd}$ & $49.4 \mathrm{~b}$ \\
\hline Mor-Bor 17 & $93.6 \mathrm{c}$ & $83.0 \mathrm{~b}$ & $62.5 \mathrm{~b}$ & $108.5 \mathrm{~b}$ & $39.8 \mathrm{~b}$ \\
\hline N-Boron & $89.2 \mathrm{bc}$ & $96.0 \mathrm{~b}$ & 109.9 de & $189.4 \mathrm{~cd}$ & $49.8 \mathrm{~b}$ \\
\hline Solubor & $102.9 \mathrm{c}$ & $84.3 \mathrm{~b}$ & $102.6 \mathrm{~cd}$ & $203.5 \mathrm{~d}$ & $38.4 \mathrm{ab}$ \\
\hline Solubor+Coron & $106.2 \mathrm{c}$ & $106.6 \mathrm{~b}$ & $126.2 \mathrm{e}$ & $185.8 \mathrm{~cd}$ & $41.1 \mathrm{~b}$ \\
\hline Solubor DF & $93.5 \mathrm{c}$ & $86.1 \mathrm{~b}$ & $109.7 \mathrm{de}$ & $161.5 \mathrm{bcd}$ & $36.5 \mathrm{ab}$ \\
\hline Spraybor & $81.8 \mathrm{bc}$ & $84.9 \mathrm{~b}$ & $85.8 \mathrm{c}$ & $138.3 \mathrm{bc}$ & $41.7 \mathrm{~b}$ \\
\hline F statistic ${ }^{\mathrm{x}}$ & 6.78 & 5.53 & 24.57 & 12.14 & 2.86 \\
\hline Probability $^{w}$ & 0.0001 & 0.0001 & 0.0001 & 0.0001 & 0.0118 \\
\hline \multicolumn{6}{|c|}{ Boron concentration in midsummer leaves $\left(\mathrm{mg} \cdot \mathrm{kg}^{-1}\right)$} \\
\hline Water control & 36.3 & $20.8 \mathrm{a}$ & 16.0 & $18.5 \mathrm{a}$ & 28.0 \\
\hline Solubor, soil & 39.5 & $28.0 \mathrm{c}$ & 20.2 & $29.6 \mathrm{bc}$ & 36.2 \\
\hline Borosol & 34.4 & $20.5 \mathrm{a}$ & 21.0 & $29.8 \mathrm{bc}$ & 33.6 \\
\hline Liquibor & 39.8 & $25.6 \mathrm{abc}$ & 23.5 & $27.4 \mathrm{bc}$ & 35.5 \\
\hline Mor-Bor 17 & 36.3 & $27.3 \mathrm{bc}$ & 21.5 & $26.9 \mathrm{bc}$ & 31.4 \\
\hline N-Boron & 36.9 & $24.0 \mathrm{abc}$ & 21.9 & $30.1 \mathrm{c}$ & 35.6 \\
\hline Solubor & 38.7 & $25.4 \mathrm{abc}$ & 18.8 & $28.9 \mathrm{bc}$ & 34.8 \\
\hline Solubor+Coron & 37.4 & $21.2 \mathrm{ab}$ & 22.3 & $29.8 b c$ & 35.7 \\
\hline Solubor DF & 36.6 & $28.1 \mathrm{c}$ & 20.5 & $23.1 \mathrm{ab}$ & 32.1 \\
\hline Spraybor & 36.5 & $25.9 \mathrm{abc}$ & 20.0 & $28.1 \mathrm{bc}$ & 35.6 \\
\hline F statistic & 1.10 & 2.29 & 1.13 & 3.23 & 1.63 \\
\hline Probability & 0.3862 & 0.0379 & 0.3673 & 0.0057 & 0.1441 \\
\hline
\end{tabular}

${ }^{\mathrm{z} B}$ application rates: $0.56 \mathrm{~kg} \cdot \mathrm{ha}^{-1}$ in 1996-98; $1.12 \mathrm{~kg} \cdot \mathrm{ha}^{-1}$ in 1999; none (2000).

${ }^{\mathrm{y}}$ Mean separation in columns by Duncan's multiple range test at $P=0.05$.

${ }^{\mathrm{x}} \mathrm{F}$ test statistic $(9,36$ degrees of freedom).

${ }^{\mathrm{w}}$ Level of significance for $\mathrm{F}$ test.

Table 3. Effect of B spray treatments applied at the full pink flowering stage on plant tissue Na concentrations of 'Fuji' apple trees, Expt. 1.

\begin{tabular}{|c|c|c|c|c|c|}
\hline \multirow{2}{*}{$\begin{array}{l}\text { Spray } \\
\text { treatment }\end{array}$} & \multicolumn{5}{|c|}{ Year $^{2}$} \\
\hline & 1996 & 1997 & 1998 & 1999 & 2000 \\
\hline \multicolumn{6}{|c|}{ Sodium concentration in flower clusters at full bloom $\left(\mathrm{mg} \cdot \mathrm{kg}^{-1}\right)$} \\
\hline Water control & $62.4 \mathrm{a}^{\mathrm{y}}$ & $70.7 \mathrm{a}$ & $22.3 \mathrm{a}$ & $27.6 \mathrm{a}$ & 22.2 \\
\hline Solubor, soil ${ }^{\mathrm{x}}$ & $71.8 \mathrm{a}$ & $67.7 \mathrm{a}$ & $17.3 \mathrm{a}$ & $26.1 \mathrm{a}$ & 22.1 \\
\hline Borosol & $63.5 \mathrm{a}$ & $72.3 \mathrm{a}$ & $21.3 \mathrm{a}$ & $32.2 \mathrm{ab}$ & 21.3 \\
\hline Liquibor $^{x}$ & $101.1 \mathrm{~b}$ & $125.2 \mathrm{~b}$ & $92.1 \mathrm{c}$ & $189.0 \mathrm{~d}$ & 23.0 \\
\hline Mor-Bor 17 & $63.7 \mathrm{a}$ & $68.6 \mathrm{a}$ & $21.3 \mathrm{a}$ & $29.3 \mathrm{a}$ & 21.7 \\
\hline N-Boron & $61.2 \mathrm{a}$ & $72.0 \mathrm{a}$ & $20.9 \mathrm{a}$ & $31.0 \mathrm{ab}$ & 23.5 \\
\hline Solubor ${ }^{x}$ & $111.5 \mathrm{~b}$ & $117.8 \mathrm{~b}$ & $102.6 \mathrm{c}$ & $217.2 \mathrm{~d}$ & 20.6 \\
\hline Solubor + Coron $^{\mathrm{x}}$ & $117.7 \mathrm{~b}$ & $134.0 \mathrm{~b}$ & $121.5 \mathrm{~d}$ & $211.6 \mathrm{~d}$ & 21.1 \\
\hline Solubor $\mathrm{DF}^{\mathrm{x}}$ & $101.5 \mathrm{~b}$ & $117.0 \mathrm{~b}$ & $94.6 \mathrm{c}$ & $143.2 \mathrm{c}$ & 22.2 \\
\hline Spraybor $^{x}$ & $76.2 \mathrm{a}$ & $78.8 \mathrm{a}$ & $41.6 \mathrm{~b}$ & $74.0 \mathrm{~b}$ & 21.9 \\
\hline$F$ statistic $^{\mathrm{w}}$ & 22.79 & 24.22 & 136.21 & 33.66 & 0.61 \\
\hline$P^{\mathrm{v}}$ & 0.0001 & 0.0001 & 0.0001 & 0.0001 & 0.7762 \\
\hline \multicolumn{6}{|c|}{ Sodium concentration in midsummer leaves $\left(\mathrm{mg} \cdot \mathrm{kg}^{-1}\right)$} \\
\hline Water control & 92.3 & $<61^{\mathrm{u}}$ & 16.0 & 32.0 & 65.3 \\
\hline Solubor, soil ${ }^{\mathrm{x}}$ & 89.6 & $<61$ & 20.2 & 31.8 & 64.2 \\
\hline Borosol & 100.8 & $<61$ & 21.0 & 44.9 & 62.4 \\
\hline Liquibor $^{\mathrm{x}}$ & 92.4 & $<61$ & 23.5 & 51.3 & 71.5 \\
\hline Mor-Bor 17 & 102.3 & $<61$ & 21.5 & 46.5 & 67.1 \\
\hline N-Boron & 91.1 & $<61$ & 21.9 & 39.7 & 69.7 \\
\hline Solubor ${ }^{x}$ & 105.8 & $<61$ & 18.8 & 39.9 & 64.3 \\
\hline Solubor+Coron ${ }^{\mathrm{x}}$ & 95.8 & $<61$ & 22.3 & 42.6 & 69.3 \\
\hline Solubor $\mathrm{DF}^{\mathrm{x}}$ & 102.8 & $<61$ & 20.5 & 44.5 & 70.2 \\
\hline Spraybor $^{x}$ & 93.6 & $<61$ & 20.0 & 38.3 & 70.4 \\
\hline F statistic & 1.35 & NA & 0.74 & 1.91 & 0.33 \\
\hline$P$ & 0.2491 & NA & 0.6662 & 0.0821 & 0.9570 \\
\hline \multicolumn{6}{|c|}{ 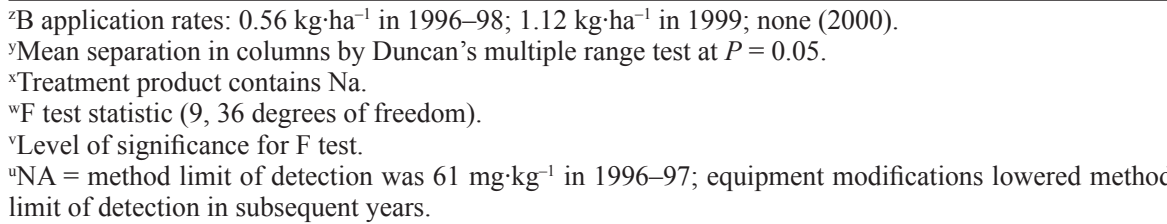 } \\
\hline
\end{tabular}

higher than the Control, indicating a residual beneficial effect of the previous four years of $\mathrm{B}$ application on tree $\mathrm{B}$ status.

Leaf B concentration was unaffected or weakly affected by B treatment in the years when the $0.56 \mathrm{~kg} \cdot \mathrm{ha}^{-1} \mathrm{~B}$ maintenance rate was used (Table 2). The response was stronger in 1999 when the B application rate was doubled. Differences between B products were nil or slight. There was no residual effect of the B treatments on leaf B concentration in 2000 . Leaf B concentration even in the B-sprayed trees was sometimes below the $25 \mathrm{mg} \cdot \mathrm{kg}^{-1}$ limit suggested by WSU as the minimum desirable for adequate apple tree B status, and in one case was lower than the $20 \mathrm{mg} \cdot \mathrm{kg}^{-1}$ value suggested as the threshold below which B deficiency is likely to occur (Tukey and Dow, 1979). These thresholds are consistent with those reported for apples worldwide (Wichmann, 1992).

Both flower cluster and leafB concentration in the Control treatment declined substantially between 1996 and 1998. Flower cluster B concentration thereafter stabilized at about 25 $\mathrm{mg} \cdot \mathrm{kg}^{-1}$, while leaf B concentration showed greater variability. The $\mathrm{B}$ status of apple trees that are not fertilized with B appears to naturally decline over a period of years (Bramlage and Weis, 1991; Peryea, 1992). High betweenseason variability is commonly observed in deciduous fruit trees even under conditions of uniform nutrient supply, and is caused by differences in weather, irrigation water management, cropping, and horticultural practices such as pruning and thinning (Bould, 1966; Righetti et al., 1990). Between-season leaf B changes for the Control treatment were as great or greater than the increases observed in any year for most of the B spray treatments.

Soil application of Solubor at pink timing had no effect on flower cluster B in 1996-99 but did produce higher flower cluster B relative to the Control treatment in 2000 (Table 2 ), indicating a positive cumulative effect of the ground application on tree B status. Leaf $\mathrm{B}$ concentration for this treatment did not appreciably differ from those of the foliarly applied B sprays.

With one exception, the B spray products formulated with Na polyborates substantially increased flower cluster $\mathrm{Na}$ concentration in the years sprays were applied (Table 3). The exception was Spraybor, which had no effect in 1996-97 and an intermediate effect in 1999-2000. Flower cluster Na concentration in the Control treatment declined substantially after 1997 and then stabilized. None of the B treatments influenced leaf $\mathrm{Na}$ concentration. Leaf Na concentration in the Control treatment was highly variable, but, as with B, increased substantially from 1998 to 2000 . Soil application of Solubor at pink timing had no effect on flower cluster or leaf $\mathrm{Na}$ concentrations.

There was no effect of the B sprays on flower cluster or leaf $\mathrm{N}$ concentrations, even for the N-containing treatments of Borosol, NBoron, and Solubor + Coron. Flower cluster N concentrations averaged across all treatments were $2.8 \%, 3.1 \%, 3.2 \%, 3.6 \%$, and $2.8 \%$ in 1996-2000, respectively. Leaf N concentrations averaged across all treatments were $2.1 \%$, 
$2.2 \%, 2.5 \%, 2.2 \%$, and $2.3 \%$ in $1996-2000$, respectively, and were consistent with values reported as optimal for 'Fuji'/M.26 by Fallahi et al. (2002a).

The experimental treatments had no effect on the concentrations of the other mineral elements, with the exception of a few inconsistent effects for some element and tissue combinations that likely were random effects (incorrect rejection of the null hypothesis). In all years, leaf $\mathrm{P}, \mathrm{K}, \mathrm{Ca}, \mathrm{Mg}, \mathrm{S}, \mathrm{Mn}, \mathrm{Fe}$, and $\mathrm{Al}$ concentrations fell within desirable ranges for apple. Suboptimal concentrations

were present for leaf $\mathrm{Zn}$ in 1996-99 (average $9.8 \mathrm{mg} \cdot \mathrm{kg}^{-1}$; increased to $49 \mathrm{mg} \cdot \mathrm{kg}^{-1}$ in 2000 when postbloom $\mathrm{Zn}$ spray was applied) and for leaf $\mathrm{Cu}$ (average $4.8 \mathrm{mg} \cdot \mathrm{kg}^{-1}$ for all years), reflecting the endemically low status of these elements occurring in Washington orchards (Peryea, 1994).

Mineral element concentrations in plant tissues, Expt. 2. Flower cluster and leaf B concentrations in the Control treatment of Expt. 2 were consistent with the Control treatment of Expt. 1 (Table 4). The Expt. 2 B-containing treatments had a very highly significant effect

Table 4. Effect of B spray treatments applied at the full pink flowering stage on plant tissue B and $\mathrm{Na}$ concentrations of 'Fuji' apple trees, Expt. 2.

\begin{tabular}{|c|c|c|c|c|c|c|}
\hline \multirow{2}{*}{$\begin{array}{l}\text { Spray } \\
\text { treatment }\end{array}$} & \multicolumn{3}{|c|}{ Boron $^{z}$} & \multicolumn{3}{|c|}{ Sodium } \\
\hline & 1998 & 1999 & 2000 & 1998 & 1999 & 2000 \\
\hline \multicolumn{7}{|c|}{ Boron and sodium concentration in flower clusters at full bloom $\left(\mathrm{mg} \cdot \mathrm{kg}^{-1}\right)$} \\
\hline Water control & $25.6 \mathrm{a}^{\mathrm{y}}$ & $26.2 \mathrm{a}$ & $28.4 \mathrm{a}$ & $24.0 \mathrm{a}$ & $40.2 \mathrm{a}$ & $43.0 \mathrm{a}$ \\
\hline Mor-Bor 17 & $78.3 \mathrm{~b}$ & $55.6 \mathrm{~b}$ & $134.4 \mathrm{~b}$ & $25.3 \mathrm{a}$ & $43.3 \mathrm{a}$ & $39.0 \mathrm{a}$ \\
\hline B-17 & $78.2 \mathrm{~b}$ & $63.0 \mathrm{bc}$ & $162.5 \mathrm{bcd}$ & $24.9 \mathrm{a}$ & $43.2 \mathrm{a}$ & $45.2 \mathrm{a}$ \\
\hline Solubor & $95.7 \mathrm{~b}$ & $63.1 \mathrm{bc}$ & $205.1 \mathrm{~cd}$ & $99.1 \mathrm{~b}$ & $78.2 \mathrm{~b}$ & $251.6 \mathrm{~b}$ \\
\hline Albion Liquid B & $119.1 \mathrm{c}$ & $87.0 \mathrm{c}$ & $214.6 \mathrm{~d}$ & $118.2 \mathrm{~b}$ & $105.6 \mathrm{c}$ & $296.0 \mathrm{c}$ \\
\hline Greenleaf B Micro & $120.5 \mathrm{c}$ & NT & NT & $289.8 \mathrm{c}$ & NT & NT \\
\hline Boron X-tra & $\mathrm{NT}^{\mathrm{x}}$ & NT & $150.8 \mathrm{bc}$ & NT & NT & $51.1 \mathrm{a}$ \\
\hline F statistic ${ }^{w}$ & 30.70 & 7.50 & 13.59 & 12.14 & 23.96 & 86.50 \\
\hline$P^{\mathrm{v}}$ & 0.0001 & 0.0013 & 0.0001 & 0.0001 & 0.0001 & 0.0001 \\
\hline \multicolumn{7}{|c|}{ Boron and sodium concentration in midsummer leaves $\left(\mathrm{mg} \cdot \mathrm{kg}^{-1}\right)$} \\
\hline Water control & 14.4 & 21.0 & $26.4 \mathrm{a}^{\mathrm{y}}$ & 34.6 & 40.1 & 67.5 \\
\hline Mor-Bor 17 & 18.5 & 26.6 & $37.1 \mathrm{bc}$ & 31.6 & 37.2 & 68.3 \\
\hline B-17 & 17.3 & 26.6 & $34.7 \mathrm{~b}$ & 29.7 & 35.8 & 66.7 \\
\hline Solubor & 19.8 & 27.5 & $41.9 \mathrm{c}$ & 33.9 & 45.4 & 80.3 \\
\hline Albion Liquid B & 19.0 & 26.6 & $39.4 \mathrm{bc}$ & 38.4 & 39.9 & 79.7 \\
\hline Greenleaf B Micro & 20.4 & NT & NT & 38.2 & NT & NT \\
\hline Boron X-tra & NT & NT & $40.2 \mathrm{c}$ & NT & NT & 75.6 \\
\hline F statistic & 1.11 & 1.37 & 12.00 & 0.57 & 2.94 & 0.54 \\
\hline$P$ & 0.3861 & 0.2885 & 0.0001 & 0.7249 & 0.0534 & 0.7430 \\
\hline
\end{tabular}

${ }^{2} \mathrm{~B}$ application rates: $0.56 \mathrm{~kg} \cdot \mathrm{ha}^{-1}$ in $1998-99 ; 1.68 \mathrm{~kg}^{-h^{-1}}$ in 2000.

${ }^{y}$ Mean separation in columns by Duncan's multiple range test at $P=0.05$.

${ }^{\mathrm{x} T}=$ not tested in that particular year.

${ }^{w} \mathrm{~F}$ test statistic (5, 20 degrees of freedom in 1998 and 2000; 4, 15 degrees of freedom in 1999).

${ }^{v}$ Level of significance for $\mathrm{F}$ test.

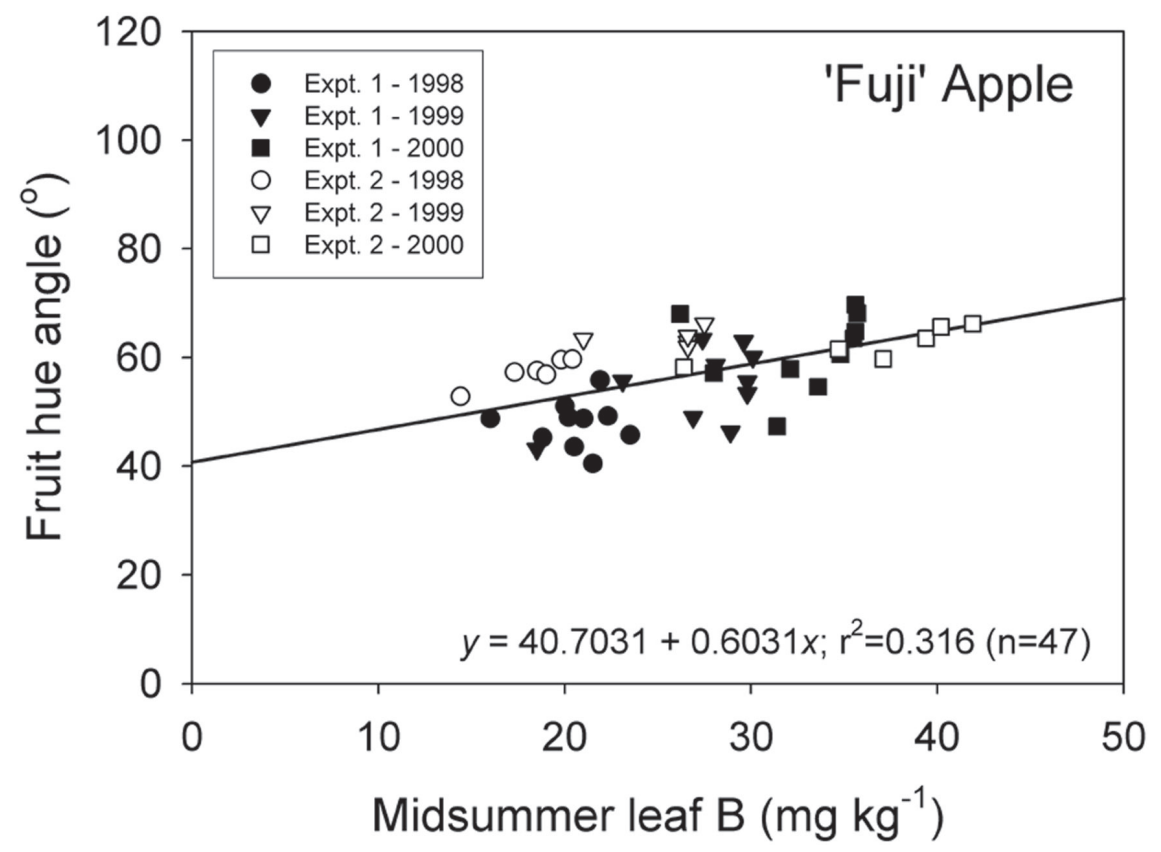

Fig. 1. Relationship between visually perceived fruit skin color (fruit hue angle: $0^{\circ}$ is red, $90^{\circ}$ is yellow) and midsummer leaf B concentration of 'Fuji' apple. on flower cluster B in every year. All of the B sprays caused flower cluster B to increase relative to the control treatment. The polyborate-based Solubor, Albion Liquid B, and Greenleaf B tended to generate higher flower cluster B than did the boric acid-based MorBor 17, B-17, and Boron X-tra. The latter three products produced equivalent flower cluster B concentrations and did not increase flower cluster Na relative to the control, consistent with the absence of $\mathrm{Na}$ in their formulations. The Na-containing Solubor, Albion liquid B, and Greenleaf B increased flower cluster $\mathrm{Na}$ relative to the control.

Although average leaf B concentration was always higher in the $\mathrm{B}$ treated trees than in the control trees, a significant treatment effect was observed only in 2000 when the B application rate was tripled compared to previous years (Table 4). Leaf B concentrations even in the $\mathrm{B}$-sprayed trees were lower than desirable in 1998. As in Expt. 1, leaf B and $\mathrm{Na}$ concentrations of the control trees increased substantially from 1998 to 2000 .

The treatments had no effect on the concentrations of the other mineral elements in either flower cluster or leaf tissue in any year, with the exception that the Albion Liquid B treatment had higher leaf $\mathrm{Cu}$ concentration than did the other treatments in 1998, likely a random effect. In all years, leaf $\mathrm{P}, \mathrm{K}, \mathrm{Ca}, \mathrm{Mg}$, $\mathrm{S}, \mathrm{Mn}, \mathrm{Fe}$, and $\mathrm{Al}$ concentrations fell within desirable ranges for apple. Leaf $\mathrm{Zn}$ and $\mathrm{Cu}$ concentrations were lower than desirable and behaved as in Expt. 1.

Fruit quality attributes, Expts. 1 and 2. In Expt. 1, the B spray treatments had no effect on any of the measured fruit quality attributes in 1998, and no effect on most of the attributes in 1999 and 2000. In 1999, significant treatment effects were observed on $L_{\mathrm{e}}, b_{\mathrm{e}}$, hue, and titratable acidity, with some of the $\mathrm{B}$ treatments showing minor differences from the control treatment for the first three variables. In 2000, $L_{\mathrm{e}}, \mathrm{a}_{\mathrm{e}}, b_{\mathrm{e}}$, and hue were significantly influenced by treatment; however, differences in mean values occurred only between B-treated plots and none of the means for B-treated plots differed from the control. Mean fruit characteristics, averaged across all treatments for each year, were (attribute, mean values for 1998, 1999, and 2000): mass, 294, 303, and $328 \mathrm{~g}$; firmness, 63, 69, and $66 \mathrm{~N}$; soluble solids concentration, $15.1 \%, 15.7 \%$, and $14.7 \%$; titratable acidity, $0.31 \%, 0.40 \%$, and $0.34 \%$ malic acid equivalent; machine peel lightness index $L_{\mathrm{e}}, 62$, 63, and 51 (higher value is lighter); machine external $a$ (red/green index), 12.4, 11.2, and 9.8; machine external $b_{\mathrm{e}}$ (yellow/blue index), 13.8, 16.4, and 17.7; and hue angle, $48^{\circ}, 55^{\circ}$, and $61^{\circ}$ degrees $\left(0^{\circ}\right.$ is red; $90^{\circ}$ is yellow). The fruit would be characterized as very large, intermediate between red and yellow color with a tendency towards yellow, firm for their large size, and high in both sugars and acidity. These are all classic attributes of 'Fuji' apple.

In Expt. 2, the B spray treatments had no effect on any of the measured fruit quality attributes in any year except for 2000 , when a weak $(P=0.0414)$ treatment effect on the $b_{\mathrm{e}}$ machine color index was observed. Average 
values for measured fruit characteristics were consistent with those observed in Expt. 1.

Haller and Batjer (1946) also reported that $B$ application produced a yellower background color of some cultivars under some conditions. In the current experiments, ANOVA indicated that a B spray-related increase in fruit yellow color appeared only occasionally. When all the data for all three years for both experiments were combined and evaluated using regression analysis, 'Fuji' apple yellowness was weakly but positively related to midsummer leaf $\mathrm{B}$ concentration (Fig. 1). These results suggest that tree B status may influence fruit red-toyellow color. The other fruit characteristics were less well related to leaf B concentration (data not shown).

\section{Discussion}

All of the tested B spray products and product combinations generated similar flower cluster and leaf B concentrations for any given year when applied at equivalent rates of actual B. The chemical form of B in the product, physical state, and presence of additives had no consistent and substantive differential effects on B phytoavailability. The small differences in flower cluster B concentration that occasionally appeared between B spray product treatments likely reflect differences in spray application efficiency, B solubility, and variable adhesiveness of B spray solution due to the presence of component surfactants and stickers. None of the differences would be considered horticulturally significant. The two dryboric acid-based products sometimes would produce lower flower cluster B concentrations than some of the other B products. Although these products theoretically are fully soluble at the concentrations used in the experimental treatments, slow reaction kinetics preclude their complete dissolution at the temperatures and within the period of time normally used to prepare and apply foliar sprays in the field. As a result, the spray is a suspension of crystalline solid particles and boric acid solution. These particles may bounce off the targeted plant tissue or adhere, dry and fall off later. The end result would be lower B concentrations measured for flower clusters at full bloom. Given the inherent high solubility of $\mathrm{Na}$ polyborate compounds, it is not surprising that adding complexing agents had no effect on B phytoavailability from foliar sprays.

Failure of the urea additives to enhance B uptake is consistent with Heitholt (1994), who reported that addition of urea to boric acid sprays on cotton failed to increase leaf B. Nitrogen applied in urea sprays is absorbed by apple leaves (Fallahi et al., 2002b; Toselli et al., 2002); hence, some of the spray-applied $\mathrm{N}$ likely was absorbed by the flower clusters and some retained as spray residue on the unwashed flower cluster surfaces. The total Kjeldahl analytical procedure measures $\mathrm{N}$ present in urea as well as in most other $\mathrm{N}$ compounds, so it should have detected $\mathrm{N}$ contributed by the N-Boron and Coron. Failure to detect an increase in plant tissue $\mathrm{N}$ concentration suggests that any spray-induced increases were less than the $100 \mathrm{mg} \cdot \mathrm{kg}^{-1}$ analytical sensitivity of the total Kjeldahl procedure, and therefore were miniscule compared to the amounts of $\mathrm{N}$ already existing in the trees and taken up from the soil.

The consistent and substantial positive effect of the B sprays on flower cluster B concentration at full bloom did not persist into the growing season. The B sprays sometimes enhanced leaf B concentration, and sometimes had no effect. The considerable influence of between-season variation substantially complicates use of leaf analysis as a tool to micromanage $B$ nutrition in order to manipulate fruit quality. There is considerable scientific basis for using fruit $\mathrm{B}$ concentration as the preferred criterion for assessing B fertilizer requirement when apple trees are not deficient in B (Bould, 1966; Bramlage and Thompson, 1962; Peryea et al., 2003).

The correspondence of leaf B concentrations in the soil-applied Solubor treatment and the sprayed $B$ treatments indicate that the trees eventually absorbed the soil-applied B after a lag period. In the experimental orchard, some time is required for the soil-applied B to leach into the rootzone (requiring rainfall because irrigation typically is not used during the bloom period), and then for the exogenous $\mathrm{B}$ to be absorbed by the tree roots, transported through the xylem into the upper portions of the tree, and accumulated in the flower clusters (root absorption and intra-tree transport are slow because of cool temperatures and small amounts of transpiring surfaces during the prebloom period). These physical and biological constraints slow delivery of soil-applied B to the flower clusters, but eventually some of the $\mathrm{B}$ appears in the aerial portions of the trees by midsummer.

Both the soil and pink spray applications of $B$ over a period of years appear to have enhanced the background B status of the trees by the same degree. Many of the processes controlling B uptake will be similar in both fertilization practices. Sprayed B not adhering to and absorbed by above-ground tree surfaces eventually drifts or washes onto the soil where it is available for root uptake. Some B in senescing leaves is reabsorbed by subtending twigs and $\mathrm{B}$ in decomposing fallen leaves is made available for root uptake. The importance of application method and timing appears to be less important in a sorbitol-rich plant species such as apple, in which B is phloem-mobile and can be transported within the plant to satisfy transitory B demands (Brown, 2001). While transient $B$ deficiency of reproductive parts can be a particular problem at flowering time in deciduous tree fruit species, it should be of little concern if overwintering B reserves are adequate in the flower buds and nearby branches (Batjer and Rogers, 1953; Callan et al., 1978; Hanson and Breen, 1985).

The apple fruit quality results of the current experiment are consistent with other experiments where B was applied but not in excess. Soil applications of B (Haller and Batjer, 1946) and early-season sprays of Solubor (Bramlage and Thompson, 1962) had no effect on apple fruit firmness, soluble solids concentration, and titratable acidity. The fruits in the control plots were of excellent quality even though the control treatments had leaf B concentrations as low as $16 \mathrm{mg} \cdot \mathrm{kg}^{-1}$. Applying the B sprays at any of the tested rates failed to improve upon this quality, implying that the fruit already contained adequate amounts of B despite low leaf B concentration. Apple trees can exhibit leaf $\mathrm{B}$ concentrations as low as $15 \mathrm{mg} \cdot \mathrm{kg}^{-1}$ without apparent ill effect (Askew, 1935; Bramlage and Thompson, 1962; Burrell et al., 1956; Woodbridge, 1937). Fruit symptoms of B deficiency are more commonly expressed than are vegetative symptoms, which normally appear only under circumstances of extreme deficiency (Oberly and Boynton, 1966). Numerous authors have concluded that the greatest demand of apple for B was early in the growing season (e.g., Johnson and De Long, 1937); hence, the high B concentrations in the flower clusters in the current experiments should preclude B insufficiency-related pollination and fruit set problems. Based on 'Gala' apple behavior, the pink B sprays would generate increased fruit B concentration (Peryea et al., 2003), which would account for failure to find impaired fruit quality even in the presence of low leaf B concentration.

Application of B at the recommended annual maintenance rate of $0.56 \mathrm{~kg} \mathrm{ha}^{-1}$ failed to maintain leaf B concentration at a desirable level. The WSU spray guide currently recommends an annual B maintenance rate of 1.12 $\mathrm{kg} \cdot \mathrm{ha}^{-1}$ (applied in two or more sprays) for orchards planted on irrigated sandy or calcareous soils, or on nonirrigated soils (Smith, 2004). In the current experiments, increasing the $\mathrm{B}$ application rate to 1.12 or $1.68 \mathrm{~kg} \cdot \mathrm{ha}^{-1}$ produced consistently detectable and not excessive increases in leaf B concentrations. While this result suggests that the higher maintenance rate perhaps should be applied to loamy sand and coarse sandy loam soils as well, the Expt. 1 results indicate that B spray application for four years did contribute to enhanced background $B$ status of the trees. A preferable alternative to using a fixed B maintenance rate, which inadvertently could induce B toxicity, would be to develop a quantitative procedure for estimating tree B status before B is applied.

The amounts of $\mathrm{Na}$ in the Na polyboratebased products applied at commercial fertilizer rates were apparently too low to induce $\mathrm{Na}$ toxicity or impair fruit quality. Leaf $\mathrm{Na}$ concentrations in the B-sprayed trees were less than $106 \mathrm{mg} \cdot \mathrm{kg}^{-1}$, substantially lower than the 2500 to $5000 \mathrm{mg} \cdot \mathrm{kg}^{-1}$ threshold above which $\mathrm{Na}$ toxicity is expected to occur (Ayers and Wescot, 1979).

\section{Conclusions}

The results of these experiments on 'Fuji' apple indicate that all of the tested B products were equally effective at increasing flower cluster B, and sometimes leaf B, when applied in a single-product spray at pink flowering timing. Boron application rate was more influential than was B source. The presence of $\mathrm{N}$ compounds or other additives did not influence B phytoavailability. The amount of $\mathrm{Na}$ 
contributed by Na polyborate-based products applied at commercial rates was too small to be of concern. The criteria for choosing among the $\mathrm{B}$ products therefore should be based on other properties of the products, such as cost per unit $\mathrm{B}$, reaction in spray tank mixes, and ease of handling. The inconsistent effect of the pink timing sprays on leaf B suggests that an additional post-bloom spray may be useful to satisfy vegetative tissue $\mathrm{B}$ demands. The results also confirm the need for application of B maintenance sprays to maintain desirable leaf B levels. Because of the substantial influence of inter-seasonal variation, the B application rate should be determined by sitespecific information rather than by blanket recommendation if precise management of $\mathrm{B}$ nutrition is desired.

\section{Literature Cited}

Askew, H.O. 1935. The boron status of fruit and leaves in relation to 'internal cork' of apples in the Nelson district. N.Z. J. Sci. Technol. 17:388-391.

Ayers, R.S. and D.W. Wescot. 1979. Water quality for agriculture. Food Agr. Org. United Nations, Irr. Drain. Paper 29.

Batjer, L.P. and B.L. Rogers. 1953. "Blossom blast" of pears: An incipient boron deficiency. Proc. Amer. Soc. Hort. Sci. 62:119-122.

Bould, C. 1966. Leaf analysis of deciduous fruits, $p$. 651-684. In: N.F. Childers (ed.). Nutrition of fruit crops. Rutgers Univ., New Brunswick, N.J.

Bramlage, W.J. and A.H. Thompson. 1962. The effects of early-season sprays of boron on fruit set, color, finish, and storage life of apples. Proc. Amer. Soc. Hort. Sci. 80:64-72.

Bramlage, W.J. and S.A. Weis. 1991. A re-examination of the boron recommendations for apple trees in Massachusetts. Fruit Notes 56(2):10-12.

Brown, P.H. 2001. Transient nutrient deficiencies and their impact on yield - A rationale for foliar fertilizers? Acta Hort. 564:217-223.

Burrell, A.B. 1960. Boron in apple leaves and fruits as influenced by sodium pentaborate sprays. Proc. Amer. Soc. Hort. Sci. 67:20-25.

Burrell, A.B., D. Boynton, and A.D. Crowe. 1956. Boron content of apple in relation to deficiency symptoms and to methods and timing of treatments. Proc. Amer. Soc. Hort. Sci. 67:37-46.

Callan, N.W., M.M. Thompson, M.H. Chaplin, R.L. Stebbins, and M.N. Westwood. 1978. Fruit set of 'Italian' prune following fall foliar and spring boron sprays. J. Amer. Soc. Hort. Sci. 103:253-257.

Fallahi, E., W.M. Colt, B. Fallahi, and I. Chun. 2002a. The importance of apple rootstocks on tree growth, yield, fruit quality, leaf nutrition, and photosynthesis with an emphasis on 'Fuji'. HortTechnology 12:38-44.

Fallahi, E., H. Khemira, T.L. Righetti, and A. Azarenko. 2002b. Influence of foliar application of urea on tree growth, fruit quality, leaf minerals, and distribution of urea-derived nitrogen in apples. Acta Hort. 594:603-610.

Haller, M.H. and L.P. Batjer. 1946. Storage quality of apples in relation to soil applications of boron. J. Agr. Res. 73:243-253.

Hanson, E.J. and P.J. Breen. 1985. Effects of fall boron sprays and environmental factors on fruit set and boron accumulation in 'Italian' prune flowers. HortScience 110:389-392.

Heitholt, J.J. 1994. Effects of foliar urea- and triazone-nitrogen, with and without boron, on cotton. J. Plant Nutr. 17:57-70.

Johnson, F., D.F. Allmendinger, V.L. Miller, and D. Polley. 1955. Fall application of boron sprays as a control for blossom blast and twig dieback of pears. Phytopathology 45:110-114.

Johnson, J.C., and W.A. De Long. 1937. Boron content of apples at different stages of development. Plant Physiol. 12:219-220.

Maas, E.V. 1986. Salt tolerance of plants. Appl. Agr. Res. 1:12-26.

McLarty H.R, E.B. Wilcox, and C.G. Woodbridge. 1936. The control of drought spot and corky core of the apple in British Columbia. Proc. Wash. State Hort. Assn. 32:142-146.

Oberly, G.H., and D. Boynton. 1966. Apple nutrition, p. 1-50. In: N.F. Childers (ed.). Nutrition of fruit crops. Rutgers Univ., New Brunswick, N.J.

Overholser, E.L., F.L. Overley, and L.B. Wooten. 1937. Boron in horticulture. Proc. Wash. State Hort. Assn. 33:73-86.

Peryea, F.J. 1992. History of boron research in apples, pears reviewed. Good Fruit Grower 43:26-29.

Peryea, F.J. 1994. Managing micronutrients in Northwest orchards. Good Fruit Grower 45(5):42,44-45,47.
Peryea, F.J., and J.M. Lageschulte. 2000. Boron fertilizer product and concentration influence spray water pH. HortTechnology 10:350-353.

Peryea, F.J., D. Neilsen, and G. Neilsen. 2003. Boron maintenance sprays for apple: Early-season applications and tank-mixing with calcium chloride. HortScience 38:542-546.

Phillips, W.R. and F.B. Johnston. 1943. The effect of boron applications on the subsequent storage and physiological behavior of McIntosh apples. Sci. Agr. 23:451-460.

Righetti, T.L., K.L. Wilder, and G.A. Cummings. 1990. Plant analysis as an aid in fertilizing orchards, p. 563-601. In: R.L. Westerman (ed.). Soil testing and plant analysis. 3rd ed. Soil Sci. Soc. Amer. Book Ser. 3

Shorrocks, V.M. and D.D. Nicholson. 1980. The influence of boron deficiency on fruit quality, p. 103-108. In: D. Atkinson, J.E. Jackson, R.O. Sharples, and W.M. Waller (eds.). Mineral nutrition of fruit trees. Butterworth, London.

Shu, Z.H., G.H. Oberly, E.E. Cary, and M. Rutzke. 1994. Absorption and translocation of boron applied to aerial tissues of fruiting 'Reliance' peach trees. HortScience 29:25-27.

Smith, T.L. 2004. 2004 crop protection guide for tree fruits in Washington. Wash. State Univ. Coop. Ext. Bul. EB0419.

Steel, R.G.D. and J.H. Torrie. 1980. Principles and procedures of statistics. McGraw-Hill, New York.

Toselli, M., M. Tagliavini, M. Thalheimer, N. Paoli, K. Le Bris, D. Scudellari, and P. Gioacchini. 2002. Leaf uptake and tree partitioning of urea-N as affected by concentration and volume of sprayed solution and leaf age of apple trees. Acta Hort. 594:591-594.

Tukey, R.B., and A.I. Dow. 1979. Nutrient content -Fruit trees. Wash. State Univ. Coop. Ext. Fert. Guide FG-28f.

Washington State College. 1953. Spray recommendations for tree fruits in eastern Washington, 1953. State Coll. Wash. Ext. Bul. 419.

Washington State College. 1958. Spray recommendations for tree fruits in eastern Washington, 1958. State Coll. Wash. Ext. Bul. 419.

Wichmann, W. 1992. World fertilizer use manual. Intl. Fert. Ind. Assn., Paris, France.

Woodbridge, C.G. 1937. The boron content of apple tissues as related to drought spot and corky core. Sci. Agr. 18:41-48. 